\title{
Relation between perceived emotional intelligence and social factors in the educational context of Brazilian adolescents
}

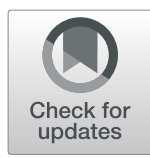

\author{
M. Vaquero-Diego(D, P. Torrijos-Fincias and M. J. Rodriguez-Conde*
}

\begin{abstract}
Background: The study of emotional intelligence (EI), demographics, and family factors of adolescent high school students allows us to appraise adolescents' skills for their academic and vocational training. The objectives of the study focus on whether there is any relationship between context variables such as gender, age of parents, or work activity, and self-perception of emotional intelligence.

Methodology: This study sampled 11.370 participants, aged between 12 and 17 years, in the 7th and 9th years of fundamental education, and the 3rd year of upper secondary education. Data from this study comes from students enrolled in the SESI schools of the City of Sao Paulo. To examine the data, we applied the TMMS-24 test to statistical analysis where gender relates to the three dimensions of perceived emotional intelligence (PEI): attention, clarity, and emotional repair.

Results: The results obtained allow us to show how teenagers are perceived with respect to three dimensions: attention, clarity and emotional repair, and thereby extrapolating the need to continue the promotion of emotional education in schools.

Conclusions: Our findings suggest that the application of the Brazilian version of the TMMS-24 in training programs in PEI must consider a whole series of sociocultural aspects. These aspects should start with a series of initial measures that allow for the perceptions of participants to be observed, and to extend onward to influence the willingness of the beneficiaries to participate in this type of intervention. Provided the intervention is anchored in a solid theoretical base, and executed under a rigorous study, its efficacy can be verified.
\end{abstract}

Keywords: Emotional intelligence, Adolescence, Gender, TMMS-24

\section{Background}

The concept of emotional intelligence (EI) refers to the capability of individuals to recognize their own emotions and the mental ability to understand human relations as a key element in the educative process (Campo et al., 2015). Research related to this field shows that the EI influences behavior and self-perception of well-being. It has a fundamental role in social interactions, the contents of thought, and the processes involved in forming them (Brackett et al., 2011; Zurita-Ortega et al., 2018). Therefore, the concept of EI has implications on

\footnotetext{
* Correspondence: mjrconde@usal.es

Department of Didactics, Organization and Research Methods, Institute of Education Sciences, University of Salamanca, Paseo Canalejas, 169, 37008 Salamanca, Spain
}

indicators of adjustment and well-being relating to one's health and the ability to cope with life's vital challenges (Vergara et al., 2015). EI is recognized by the scientific community from the contributions of renowned researchers such as Salovey and Mayer, 1990.

There are two theoretical models of EI can be distinguished based on current scientific literature and its theoretical nature from which it starts. The first, models based on the processing of emotional information, facilitating the use of our own emotions for the management of a more intelligent thinking and its more effective reasoning; from which EI is conceived as the ability to perceive, understand, manage, and regulate emotions, both their own and those of others such as with Mayer (1997) (Fig. 1), and second, the so-called mixed based on 


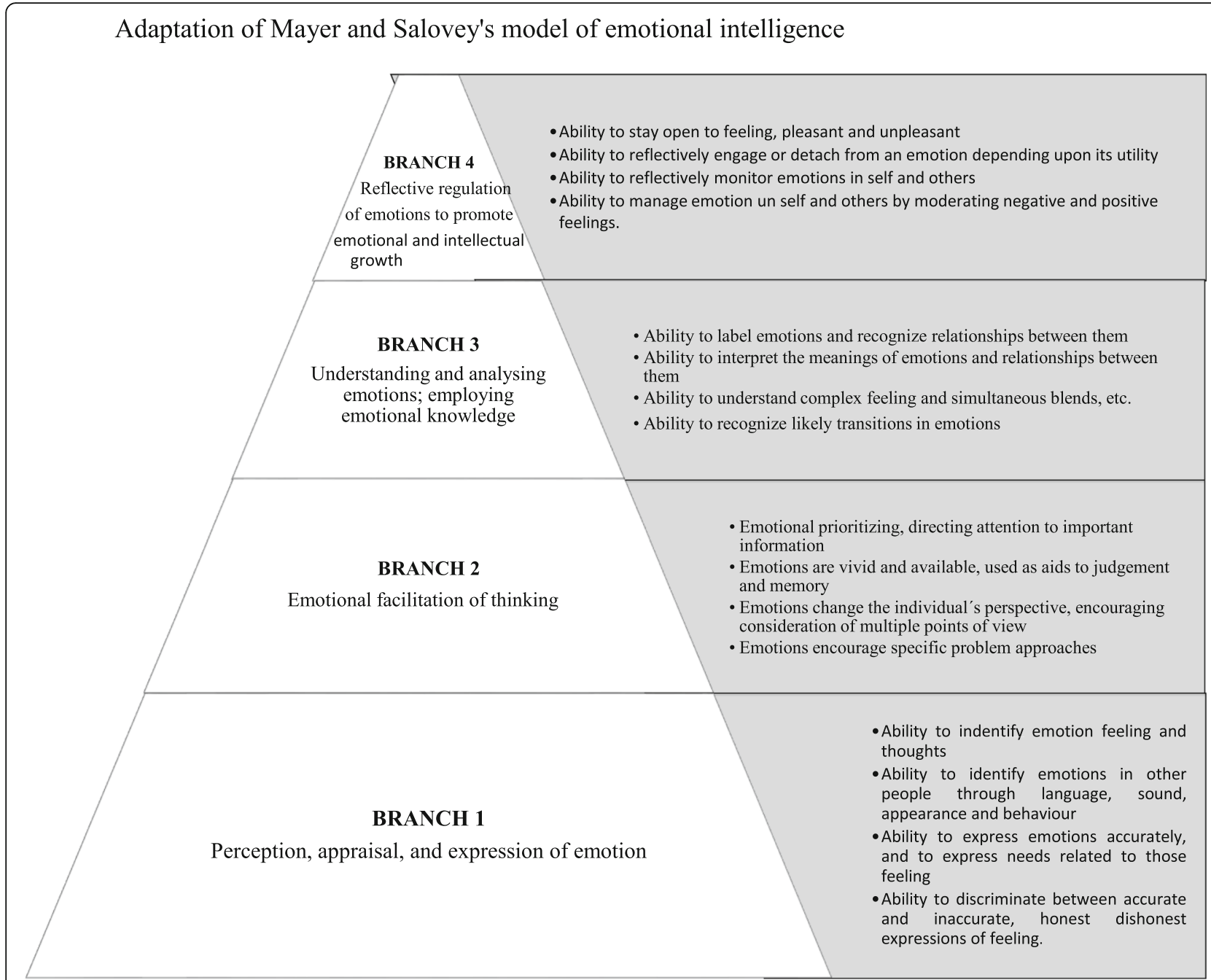

Fig 1 Adaptation of the IE Model by Mayer (1997)

personality traits such as the Bar-On models (2000) that describe a cross-section of interrelated socio-emotional competencies, as well as the skills and facilitators that would affect intelligent behavior (Fernández-Berrocal and Pacheco, 2005; Goleman, 1996; Pena Garrido \& Repetto Talavera, 2017).

These authors statement that EI was conceived as a set of skills hypothesized to contribute to the accurate appraisal and expression of emotion in oneself and others, the effective regulation of emotion in self and others and the use of feelings to motivate, plan and achieve in one's life (Salovey and Mayer, 1990). This model of Mayer and Salovey contemplates four capacities: one, perception and expression of emotions; two, emotional facilitation of thought; three, understanding and analyzing emotional information; and four, the regulation of emotions.

From this theory, numerous definitions have been proposed for the term EI; however, the meeting point between the different theories and the acceptance of the series of emotional competencies must be well understood and that constituted a crucial factor to favor the adaptation and development of the person in all areas and vital cycles, which can be developed (Durlak et al., 2011).

\section{The implication of El in education}

The role given to the area of emotional intelligence (EI) in the social sciences as a key aspect and guarantee for well-being, contemplating a series of capacities that are related to academic performance or the improvement of coexistence in the classroom and without a doubt, they are a judge for the success both in the academic and professional fields (Bar-On \& Parker, 2000; Dolev \& Leshem, 2017; Gilar-Corbi et al., 2018; Gutiérrez-Moret et al., 2016). Scientific studies have established the fact that high levels in these capacities have a causal relationship to better physical and mental health, greater well- 
being, as well as better social functioning and school performance (Fernández-Berrocal and Ruiz Aranda, 2017). Educational centers, and more specifically schools, have focused on the development of the academic aspects of education, while often neglecting the social and emotional aspects that impact the proper functioning of the classroom, not to mention students' personal and social well-being (Ghanizadeh \& Royaei, 2015; Madalinska-Michalak, 2015).

\section{The observation of the El in adolescents}

Adolescence is considered a crucial period in a person's emotional growth. It is when the need to develop emotional competencies and strengths for well-being manifest themselves, and the response patterns to different situational triggers are apparent (Arias \& Zafra, 2011).

There are studies that report that adolescents have a high rate, approximately 10 to $20 \%$ of the general population, in the prevalence of problems related to emotional disturbances typical of anxiety and depression disorders (Salavera et al., 2019).

Leaders in education who interact with students recognize that the family plays a very important role in their students' lives. There is a risk to the student when the structure and the dynamics of the family are factors that lead to a crisis or socio-emotional problems. Likewise, schools and youth educational centers can help with socio-emotional difficulties through keeping and enhancing healthy relations with other classmates and teachers. Consequently, educational centers have a key role in the development and the self-affirmation of a student's personality and self-image and are a central aspect in one's evolution as a human being (López de Dicastillo Rupérez, N., Iriarte Redín, C. y González Torres, M., 2006).

From the standpoint of the multitude of changes and the need for biopsychosocial adaptations through which the adolescent might passes, they respond to moments where it is demanded and tend to violate norms and have problems to maintain the order demanded. (Fernández-Berrocal \& Extremera, 2006; Mayer, 1997).

A considerable amount of research interest has focused on the relationship between variables such as emotional competence and self-esteem, psychological well-being, mental health, and life satisfaction (Furr \& Funder, 1998; Huebner, 1991; Montes-Berges \& Augusto-Landa, 2014). Yet, over the past few years, we have seen that there is a lack of studies showing evidence of adolescents' self-perceived needs according to their socio-emotional development or Perceived emotional intelligence (PEI) (Toussaint et al., 2015). For this reason, it is necessary to carry out experimental studies in this field in order to see to what degree they support the theoretical models, which are not well understood.
There are currently psychometric instruments based on the Meta-Mood Scale (TMMS-24) models that can be applied as a test (Fernandez-Berrocal et al., 2004) allowing the assessment of emotional intelligence. The TMMS-24 is a useful instrument in evaluating an adolescent's PEI (Parker et al., 2004). The lack of data for the application of PEI assessments using these instruments and methods in developing countries leads study groups in the social sciences to use these tools in young students in high school (Saucedo et al., 2018). Besides acting as a model for translation and adaptation of the instrument to their educational systems, obtaining data from the application of these instruments may contribute to a better understanding of PEI in adolescents.

In that scenario, the present study must show the main objectives to evaluate the PEI of adolescents in network high schools of São Paulo City in Brazil. This school network is under the direction of the Industrial Social Service (SESI-SP) that is a state organization of private law and structured on a federative basis to provide social and educational assistance. The institution allowed us access and data collection in schools.

Based on the premise of the influence from some variables of contextual factors such as gender, course level, age and parental work activity, we propose the following two initial hypotheses: (1) there are significant differences in adolescents' self-perceived abilities related to gender, age, and parents' professional activities, and (2) the variable such as gender, age, and parents' professional activities influence in the development of emotional competences in adolescents at network high school (SESI-SP).

\section{Methods}

\section{Participants}

The total of sample in the study was established from the entirety of the students at network high school (SESI-SP), based on the available subjects enrolled in the courses in the 7th and 9th year of fundamental education, and the 3rd year of secondary education; the criterion to include these courses is because they are groups evaluated through the School Performance Evaluation System of the State of São Paulo (SARESP), with the anticipation of conducting possible research in the future and because the educational courses correspond to the 3 stages of adolescence considered by authors such as Aberastury (2002) and Blos (1986). Of a total of 14,000 students to whom the questionnaire was sent, the response was $81 \%$, of whom 5,584 were male students (49.1\%) and 5,699 were female (50.1\%), presenting a very balanced proportion by gender. There was a total of 11370 responses, of which complete data represents $n=$ 11283. This study meets the ethical considerations of the Declaration of Helsinki and the criteria of ethical 
research applied to human beings, and the director of the Education Division at SESI-SP authorized the conducting of this investigation, as well as the gathering of parental authorizations of test subjects.

\section{Design and data analysis}

The proposed research design is of a quantitative nature, developed through a descriptive-correlational study that will allow us to know the distribution of the variables, as well as the inter-correlation between them (Alzina, 2004; Arnal et al., 1992). The study of the data collected after the application of the TMMS-24 test was carried out through statistical analyzes supported by the statistical program SPSS version 23 (Campus License of the University of Salamanca). Based on the first descriptive analysis and characteristics of the variables, we proceeded to study the relationship between them, using techniques such as chi-square statistics, level of significance, and effect size because they are discrete variables.

\section{Variables}

The variables that constitute this study collected through the online questionnaire are the 24 corresponding TMMS-24 items, variable for gender, course levels, and parental employment status.

According to age, $20.6 \%$ of 7 th grade students participated in basic education (average age 11.96 years), 38.0\% of 9th grade students (average age 13.60 years), and $41 \%$ of students in the third year of secondary education (average age of 16.45 years).

The sociodemographic characteristics of the sample, as evidenced in Table 1, show similar percentages in terms of gender and occupation, reporting that $72 \%$ of mothers work compared to $88 \%$ of fathers. However, there are slightly higher percentages of mothers who are in a situation of professional inactivity (Table 2), i.e., mainly engaged in household chores.
Table 2 Sample description, gender, level, and employment situation of parent data

\begin{tabular}{llll}
\hline & & $f$ & $\%$ \\
\hline Gender & Men & 5584 & 49.1 \\
& Women & 5699 & 50.1 \\
& Sample error & 87 & 0.8 \\
Level of study & 7th fundamental year (12-13 years old) & 2339 & 20.6 \\
& 9th fundamental year (14-15 years old) & 4323 & 38.0 \\
& 3rd middle school (17-18 years old) & 4708 & 41.4 \\
& Sample error & 0 & 0 \\
Situation (father) & Work & 10054 & 88.4 \\
& DK/NR & 71 & 0.6 \\
& No work & 1158 & 10.2 \\
& Sample error & 87 & 0.8 \\
Situation (mother) & Work & 8230 & 72.4 \\
& DK/NR & 46 & 0.4 \\
& No work & 3007 & 26.4 \\
& Sample error & 87 & 0.8 \\
\hline
\end{tabular}

DK don't know, NR no reply

\section{Instrument}

For this investigation, the Spanish Modified Version of the Trait Meta-Mood Scale: TMMS-24 was used (Fernandez-Berrocal et al., 2004). This is a reduced version of the Trait Meta-Mood Scale: TMMS 48 of the research group of Salovey et al. (1995). It is composed of the 3 dimensions of the original scale: (1) attention to emotions, perception skills, and the ability to detect and express one's feelings properly; (2) emotional clarity, related to the understanding of emotions; and (3) emotional repair, meaning the ability to regulate emotional states. The reliability for each component obtained in this investigation by Mayer and Salovey was as follows: attention $\alpha=$ .90 , clarity $\alpha=.90$, and repair $\alpha=.86$.

To demonstrated efficiency, we used the reduced version of TMMS - 24 (Salovey et al., 1995) with 8 items

Table 1 Interpretation of the scores of TMMS-24 of Fernandez-Berrocal et al., 2004

\begin{tabular}{|c|c|c|c|}
\hline & Men & Women & Valuation \\
\hline \multirow[t]{3}{*}{ Attention $=$ sum of variables from 1 to 8} & $\leq 21$ & $\leq 24$ & Low. should improve \\
\hline & From 22 to 32 & From 25 to 35 & Suitable, medium \\
\hline & $\geq 33$ & $\geq 36$ & High, should improve \\
\hline \multirow[t]{3}{*}{ Clarity $=$ sum of variables from 9 to 16} & $\leq 25$ & $\leq 23$ & Low, should improve \\
\hline & From 26 to 35 & From 24 to 34 & Suitable, medium \\
\hline & $\geq 36$ & $\geq 35$ & Excellent, high \\
\hline \multirow[t]{3}{*}{ Repair $=$ sum of variables from 16 to 24} & $\leq 23$ & $\leq 23$ & Low, should improve \\
\hline & From 24 to 35 & From 24 to 34 & Suitable, medium \\
\hline & $\geq 35$ & $\geq 35$ & Excellent, high \\
\hline
\end{tabular}

Low, should improve (L); suitable, medium (S); high (H) 
per dimension and with the objective of evaluating the self-perceived EI for each dimension. Students were asked to evaluate the degree to which they agree with each of the items on a Likert-type scale of 5 points $(1=$ No agreement, $5=$ Strongly agree). This instrument classifies the dimensions attention, clarity, and repair in the values: low should improve (L), suitable, average (S), and high $(\mathrm{H})$. The interpretation of the results are based on Table 1 (adaptation Fernandez-Berrocal et al., 2004).

\section{Procedure}

Prior to the application of the questionnaire, a translation and adaptation to the Brazilian context were carried out with the participation of the NUPIC study group. The questionnaire was applied in an online format, using the Google Forms platform, and with the collaboration of professors. In each of the instances, they had received training on the questionnaire for its correct application.

This research was carried out during the months of September, October, November and December 2017 in the network of SESI-SP schools. Meetings were held with the director of the SESI-SP education division as well as with different advisors and teachers, along with the director of the study group (NUPIC) to elucidate the objectives of this research and ensure the collaboration of teachers and verify relevant permits were held by each educational unit.

\section{Results}

\section{Self-perception of El according to the gender of the participants}

The study of descriptions in Table 3 shows a greater proportion of low scores in the three dimensions of the study in the case of women, with men only holding a slightly higher percentage of high scores in the dimension of emotional attention (17.7\%).
The data obtained in this study regarding the dimensions of emotional self-perception regarding the gender of the participants show that for the female gender they have a higher proportion of low values than men, although the proportion of women, $53.0 \%$, coincides with that of men, $53.1 \%$. Regarding the clarity dimension, the proportion of women with low clarity, $44.9 \%$, is much higher than that of men, $29.7 \%$. These are unlike the case of suitable values where men represent $60.7 \%$, and women $46.3 \%$. The same applies to the repair dimension, but with a less pronounced difference. According to each of the dimensions of PEI studied, the proportions that suggest the need for improvement in the female gender are the dimensions of emotional regulation and emotional clarity.

Pearson's chi-square test for categorical variables indicates that there is significance at the 0.05 level in the difference of proportions in the three dimensions. Therefore, there are significant differences between the population of men and women in terms of the PEI dimensions, and based on the size of the effect according to the Cramer's V estimator, is considered small (Cohen, 1988) for the three dimensions.

\section{Self-perception of El according to the level of studies of the participants}

According to the data in Table 4 it is observed that there is a considerable proportion of participants who obtain low scores in all three dimensions and at all educational levels (between 30\% and 40\%). These results indicate a possible need for improvement in these capacities. The highest percentage for low values (39\%) is given in the clarity dimension when students exceed 14 years of age, which corresponds to the 9th grade.

The high values in the attention dimension increase as they move through the different stages of the educational system (7th grade $10.7 \%$, 9th grade $11.3 \%$, and 3rd grade $17.4 \%)$. Considering that both variables are categorical, for

Table 3 Gender proportions in each dimension of Emotional Intelligence Perceived (EIP); Test Chi-Squared and Effect sizes for Cramer's V

\begin{tabular}{|c|c|c|c|c|c|c|c|c|}
\hline & & \multicolumn{2}{|l|}{ Men } & \multicolumn{2}{|c|}{ Women } & \multicolumn{2}{|c|}{ *Pearson's chi-square tests } & \multirow[t]{2}{*}{ Effect Size } \\
\hline & & $f$ & $\%$ & $f$ & $\%$ & & & \\
\hline \multirow[t]{3}{*}{ Attention } & Low & 1630 & 29.2 & 2127 & 37.3 & $x^{2}$ & 189.36 & 0.13 \\
\hline & Suitable & 2963 & 53.1 & 3019 & 53.0 & df & 2 & \\
\hline & High & 991 & 17.7 & 553 & 9.7 & Sig. & 0 & \\
\hline \multirow[t]{3}{*}{ Clarity } & Low & 1657 & 29.7 & 2560 & 44.9 & $x^{2}$ & 287.25 & 0.16 \\
\hline & Suitable & 3391 & 60.7 & 2639 & 46.3 & df & 2 & \\
\hline & High & 536 & 9.6 & 500 & 8.8 & Sig. & 0 & \\
\hline \multirow[t]{3}{*}{ Repair } & Low & 1517 & 27.2 & 2468 & 43.3 & $x^{2}$ & 322.86 & 0.16 \\
\hline & Suitable & 3275 & 58.6 & 2567 & 45.0 & $d f$ & 2 & \\
\hline & High & 792 & 14.2 & 664 & 11.7 & Sig. & 0 & \\
\hline
\end{tabular}

*. The chi-square statistic is significant at the level. 05 
Table 4 Self-perception of emotional intelligence according to the level of studies of the participants. Test chi-squared and Effect sizes for Cramer's V

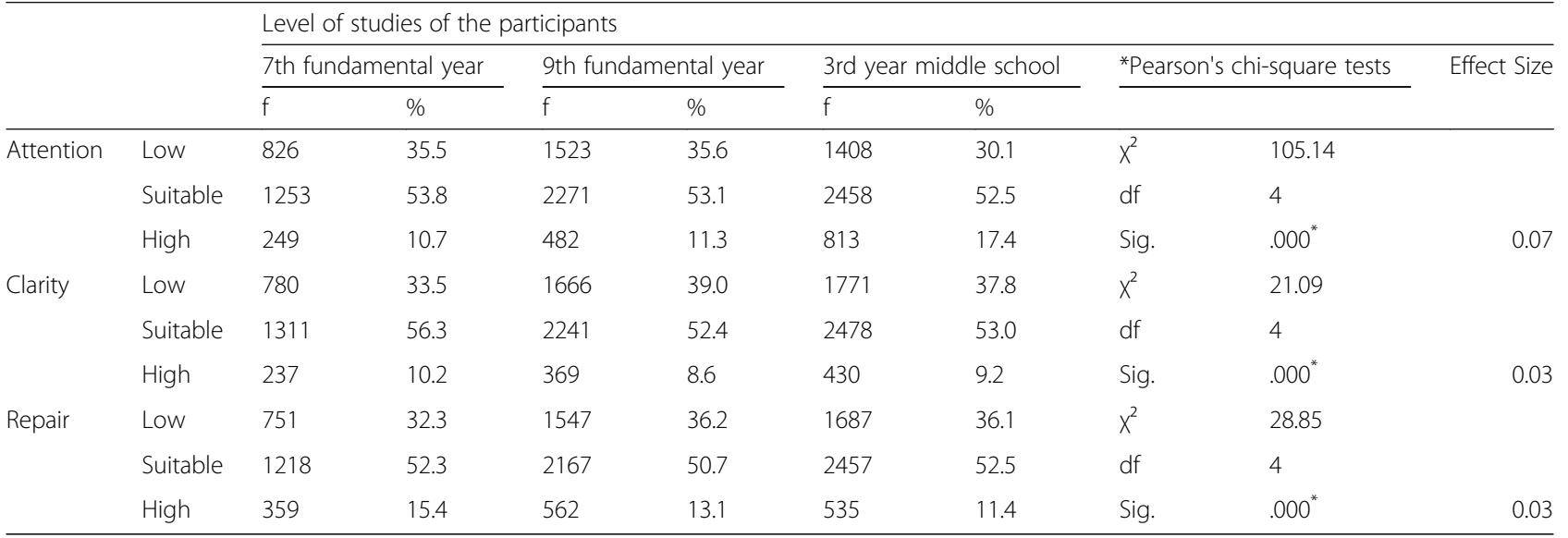

*. The chi-square statistic is significant at the level. 05

the study of the dependency relationship between variables, chi-square statistics are used, which shows a relationship between the academic level and the three dimensions of PEI, although with a low effect size. Cohen (1988) values correspond to emotional Attention $\left(\chi^{2}=\right.$ 105.144, $p=0.000$, size effect $=0.07$ ), emotional Clarity $\left(\left(\chi^{2}=21.091, p=0.000\right.\right.$ size effect $\left.=0.03\right)$, and emotional Repair $\left(\left(\chi^{2}=28.851=0.000\right.\right.$ size effect $\left.=0.03\right)$. Therefore, there is a relationship between the dimensions of emotional intelligence and the age of the participants.

\section{Self-perception of El and study of the relationship with parents' occupations}

The employment status of the parents (whose descriptive results were offered in Table 2) evidence of high employee status among fathers and mothers being slightly higher in the case of fathers $88.4 \%$, than in the case of mothers $72.4 \%$.

If we focus on the results provided by the mothers of the participants once the chi-square test has been carried out, it is observed that there is no relationship between the PEI dimensions and the employment situation, as shown in Table 5. A low proportion of the students surveyed obtain scores high in the dimensions of emotional clarity and emotional repair, with slightly higher results in these two dimensions when the mothers are actively employed. About the self-perception of emotional intelligence and the work status of parents, the study of the relationship between variables indicates that there is no significant relationship and the size of the effect is considered low (Cohen 1988), for the emotional attention dimension size effect $=0.01$, clarity size effect $=0.03$ and emotional repair size effect $=0.03$.

After carrying out a statistical analysis considering these groups: both parents work; only one of them works or neither works with PEI variable (Table 6); we observed that the group of students that both parents work showed the most percentage approx. $65.04 \%$ between the groups surveyed.

In the attention dimension, the group that reaches the highest percentage is denominated suitable and corresponds to the students whose mother worked, but the father did not work, 56.5\%. For the students who responded that their father worked, but their mother did not, the data shows the highest scores in the repair dimension, where the proportion of students who got the adequate repair of suitable was $54.0 \%$. However, the data to be highlighted were recorded when both parents were actively working with repair levels of high at $13.2 \%$.

In the group where both parents work, they present similar percentages in the three dimensions in adequate assessment of suitable, between 51 and $54 \%$. Regarding the values of low, a higher percentage in the clarity dimension stands out with $36.9 \%$. In the group where the father works and the mother does not work, with $23 \%$ of the total analyzed, there are similar percentages in the three dimensions in the appropriate assessment of suitable, which coincides with the group previously analyzed. It should be noted that the highest proportion of the values of low are in the clarity dimension at $38.0 \%$. In the group where the mother works and the father does not work, which represents $7.39 \%$, the good results that stand out in the attention dimension are with suitable, $56.5 \%$. In the clarity dimension showed low values with $39.9 \%$ of the total of groups evaluated, the same occurs in the repair dimension with one $37.3 \%$. On the other hand, we look that there a relation between the groups where none of the parents work and the attention dimension. The group of students who do not know, or do not answer because the reason for this response is unknown, is not analyzed. 
Table 5 Self-perception of emotional intelligence according to the employment situation of mothers and fathers. Test chi-squared and Effect sizes for Cramer's V

\begin{tabular}{|c|c|c|c|c|c|c|c|c|c|c|}
\hline & & \multicolumn{9}{|c|}{ Situation mother } \\
\hline & & \multicolumn{2}{|c|}{ WORK } & \multicolumn{2}{|c|}{${ }^{* *} \mathrm{DK} / \mathrm{NR}$} & \multicolumn{2}{|c|}{ NO WORK } & \multicolumn{2}{|c|}{ *Pearson's chi-square tests } & \multirow[t]{2}{*}{ Effect Size } \\
\hline & & $f$ & $\%$ & $f$ & $\%$ & $f$ & $\%$ & & & \\
\hline \multirow[t]{3}{*}{ Attention } & Low & 2720 & 33.0 & 17 & 37.0 & 1020 & 33.9 & $x^{2}$ & 6.08 & \\
\hline & Suitable & 4362 & 53.0 & 19 & 41.3 & 1601 & 53.2 & Df & 4 & \\
\hline & High & 1148 & 13.9 & 10 & 21.7 & 386 & 12.8 & Sig. & 0.19 & 0.02 \\
\hline \multirow[t]{3}{*}{ Clarity } & Low & 3063 & 37.2 & 20 & 43.5 & 1134 & 37.7 & $x^{2}$ & 2.30 & \\
\hline & Suitable & 4412 & 53.6 & 20 & 43.5 & 1598 & 53.1 & Df & 4 & \\
\hline & High & 755 & 9.2 & 6 & 13.0 & 275 & 9.1 & Sig. & 0.68 & 0.01 \\
\hline \multirow[t]{6}{*}{ Repair } & Low & 2952 & 35.9 & 18 & 39.1 & 1015 & 33.8 & $x^{2}$ & 6.03 & \\
\hline & Suitable & 4207 & 51.1 & 23 & 50.0 & 1612 & 53.6 & Df & 4 & \\
\hline & High & 1071 & 13.0 & 5 & 10.9 & 380 & 12.6 & Sig. & 0.19 & 0.02 \\
\hline & & \multicolumn{9}{|c|}{ Situation father } \\
\hline & & \multicolumn{2}{|c|}{ WORK } & \multicolumn{2}{|c|}{${ }^{* *} \mathrm{DK} / \mathrm{NR}$} & \multicolumn{2}{|c|}{ NO WORK } & \multicolumn{2}{|c|}{ *Pearson's chi-square tests } & Effect Size \\
\hline & & $f$ & $\%$ & $f$ & $\%$ & $f$ & $\%$ & & & \\
\hline \multirow[t]{3}{*}{ Attention } & Low & 3362 & 33.4 & 28 & 39.4 & 367 & 31.7 & $x^{2}$ & 5.04 & \\
\hline & Suitable & 5319 & 52.9 & 30 & 42.3 & 633 & 54.7 & $d f$ & 4 & \\
\hline & High & 1373 & 13.7 & 13 & 18.3 & 158 & 13.6 & Sig. & $.28^{\mathrm{a}}$ & 0.01 \\
\hline \multirow[t]{3}{*}{ Clarity } & Low & 3738 & 37.2 & 27 & 38.0 & 452 & 39.0 & $x^{2}$ & 2.47 & \\
\hline & Suitable & 5385 & 53.6 & 36 & 50.7 & 609 & 52.6 & $d f$ & 4 & \\
\hline & High & 931 & 9.3 & 8 & 11.3 & 97 & 8.4 & Sig. & $.65^{\mathrm{a}}$ & 0.01 \\
\hline \multirow[t]{3}{*}{ Repair } & Low & 3520 & 35.0 & 29 & 40.8 & 436 & 37.7 & $x^{2}$ & 5.50 & \\
\hline & Suitable & 5218 & 51.9 & 34 & 47.9 & 590 & 50.9 & $d f$ & 4 & \\
\hline & High & 1316 & 13.1 & 8 & 11.3 & 132 & 11.4 & Sig. & $.24^{\mathrm{a}}$ & 0.01 \\
\hline
\end{tabular}

*. The chi-square statistic is significant at the level. 05

**.(DK) Don't Know (NR) No Reply

Table 6 Self-perception of emotional intelligence according to each of these groups: both parents work, only one of them works or neither works. Pearson's chi-square test and Effect sizes for Cramer's V

\begin{tabular}{|c|c|c|c|c|c|c|c|c|c|c|c|c|c|c|}
\hline & & \multicolumn{2}{|c|}{ Both parents work } & \multicolumn{2}{|c|}{ Father work mother no } & \multicolumn{2}{|c|}{ Mother work father no } & \multicolumn{2}{|c|}{ Neither works } & \multicolumn{2}{|c|}{${ }^{* *} \mathrm{DK} / \mathrm{NR}$} & \multicolumn{2}{|c|}{${ }^{*}$ Chi-square } & \multirow[t]{2}{*}{ EffectSize } \\
\hline & & $f$ & $\%$ & $f$ & $\%$ & $f$ & $\%$ & $f$ & $\%$ & $f$ & $\%$ & & & \\
\hline $\bar{f}$ & 11283 & 7339 & 65.04 & 2674 & 23.70 & 834 & 7.39 & 321 & 2.84 & 115 & 1.02 & & & \\
\hline \multirow[t]{3}{*}{ Attention } & Low & 2441 & 33.3 & 905 & 33.8 & 257 & 30.8 & 109 & 34.0 & 45 & 39.1 & $x^{2}$ & 16.59 & 0.03 \\
\hline & Suitable & 3868 & 52.7 & 1435 & 53.7 & 471 & 56.5 & 160 & 49.8 & 48 & 41.7 & $d f$ & 8 & \\
\hline & High & 1030 & 14.0 & 334 & 12.5 & 106 & 12.7 & 52 & 16.2 & 22 & 19.1 & Sig. & $.035^{*}$ & \\
\hline \multirow[t]{3}{*}{ Clarity } & Low & 2707 & 36.9 & 1015 & 38.0 & 333 & 39.9 & 116 & 36.1 & 46 & 40.0 & $x^{2}$ & 7.35 & 0.01 \\
\hline & Suitable & 3946 & 53.8 & 1419 & 53.1 & 438 & 52.5 & 171 & 53.3 & 56 & 48.7 & $d f$ & 8 & \\
\hline & High & 686 & 9.3 & 240 & 9.0 & 63 & 7.6 & 34 & 10.6 & 13 & 11.3 & Sig. & .49 & \\
\hline \multirow[t]{3}{*}{ Repair } & Low & 2617 & 35.7 & 886 & 33.1 & 311 & 37.3 & 124 & 38.6 & 47 & 40.9 & $x^{2}$ & 13.62 & 0.02 \\
\hline & Suitable & 3753 & 51.1 & 1445 & 54.0 & 425 & 51.0 & 163 & 50.8 & 56 & 48.7 & $d f$ & 8 & \\
\hline & High & 969 & 13.2 & 343 & 12.8 & 98 & 11.8 & 34 & 10.6 & 12 & 10.4 & Sig. & .09 & \\
\hline
\end{tabular}

*. The chi-square statistic is significant at the level. 05 .

**.(DK) Don't Know (NR) No Reply 


\section{Discussion and conclusions}

For years, there has been a concern for the development of emotional competencies and reflections on the importance of promoting the development of emotional and social competences in the educational and social environment (Fundaci, \& Clouder, 2008). The new models of positive development advocate the promotion of healthy adolescent development, and that the school will be an ideal context to promote emotional competencies (Pertegal et al., 2010).

Conducting research on the relationships between PEI and factors such as gender has implications for an individual's description of their emotional development, while also informing us about the detailed needs for intervention within the classroom. In the present study, differences are perceived between males and females with respect to their emotional capacities being consistent with previous research (Gartzia et al., 2012). In addition, some research shows that certain areas of the brain dedicated to emotional processing may be larger in women than in men and that these differences are affirmed in the differentiation in the processing of emotions (Baron-Cohen, 2003; Gur et al., 2002).

In this study, women present low values in the three PEI dimensions. The values suggest that female subjects need for improvement lies in the dimensions of emotional regulation (43.3\%), and of emotional clarity (44.9\%). Similar survey results show high levels of reparation in terms of problem-solving and high social and emotional competence in men over women (Jones et al., 2002).

The female group of this study has a high percentage in the attention dimension in its value high, which is characteristic of people who care intensely about their emotions. Based on this evidence, it could highlight the great urgency with which women need to develop verbal skills and to be more competent in articulating feelings, which would allow them to have more resources and information about the emotional world (Brody, 1993). This data is in line with previous studies in which in the sample of adolescents who reported higher levels of attention in the case of women than in male students (Salguero et al., 2012). In contrast, some authors such as (Guastello \& Guastello, 2003) or (Schutte et al., 1998) argue that gender differences are getting smaller, due to socio-cultural work in terms of gender roles and stereotypes.

In other studies, the EI self-report tests show that women show higher scores in emotional attention and empathy, while men score higher in emotional regulation (Austin et al., 2005; Brackett et al., 2004; Schutte et al., 1998). These results do not correspond entirely to the sample participating in this study. The sociocultural context of the sample may be the origin of this difference in the sample.
According to the results related to the level of studies of the participants, the sample indicates that there is a considerable proportion of participants who obtain low scores in all three dimensions, results that indicate a possible need for improvement in these capacities. We consider a prominent fact that the values considered high in the attention dimension increase as they move through the different stages of the education system. Data that does not fit other studies that show younger students' express emotions such as sadness or anger with higher frequency than older students (Zeman and Garber, 1996; Zeman \& Shipman, 1996).

Therefore, an aspect important to be considered at the high school is the need to take better care of the emotional attention the students since that obtaining high values in emotional attention doesn't mean that sustains the emotional balance in the adolescents. Various studies have shown that an excessive level of emotional attention without understanding its causes or consequences, can become harmful, generating emotional fatigue (Extremera, and Fernández-Berrocal, and Durán, A., 2003).

Regarding the aspects of the study related to the relationship between parental employment and high levels of reparation, especially in the case of girls, previous studies have shown that parents tend to talk more about emotions with their daughters than with sons (Trinidad \& Johnson, 2002).

Research carried out in the Brazilian context, such as those by Andrade Neta et al., 2017, puts into perspective the need, within the education sector, to evolve both in educational policies and in the strategic vision of the high schools and the social education competencies and emotional of the students. Which is an internationally recognized need (Gurgel et al., 2016). Considering the development of EI at work or at school offers training and response to social problems, but interventions should be based solely on respectable theories and careful definition and analysis of previous emotional competencies (Zeidner et al., 2009).

In this study, based on the students' self-perception, we have studied the sociodemographic factors that should undoubtedly be considered when proposing quality socio-educational interventions, since the data shows that beliefs about success in emotional regulation are positively associated with results. Thus, the emotional factor can be considered a crucial point in improving education in schools (Bigman et al., 2016).

However, in future research, it would be interesting to use other instruments, previously adapted and translated for the Brazilian context, as has been done in the present study with the TMMS-24 instrument together with the NUPIC research team of the University of Sao Paulo. Instruments such as the MSCEITT (Mayer-Salovey-Caruso Emotional Intelligence Test) or the TIEFBA (Emotional 
Intelligence Test of the Botin Foundation for Adolescents) that mitigates some of the difficulties that arise when measuring self-report and adapt to the ages and context of the sample of population studied.

Therefore, in the application of training programs in EI we have to take into account a whole series of sociocultural aspects, based on a series of initial measures that allow not only to observe the perceptions of the participants but also to influence the willingness of participants and beneficiaries to participate in this type of intervention, being protected by a solid theoretical basis and under a rigorous study that allows to verify its effectiveness.

Consequently, the present study has implied the promotion of future research to demonstrate the impact of EI on well-being, the improvement of academic performance and the development of the ability to coexist (Fincias et al., 2018; Fundaci and Clouder, 2008).

\section{Abbreviations}

El: Emotional Intelligence; MSCEITT: Mayer-Salovey-Caruso Emotional Intelligence Test; NUPIC: Núcleo de Pesquisas em Inovações Curriculares, Faculdade de Educação da Universidade de São Paulo; PEl: Perceived emotional intelligence; SARESP: School Performance Evaluation System of the State of São Paulo; SESI-SP: Serviço Social da Indústria- of São Paulo, Brasil; TIEFBA: Emotional Intelligence Test Botin Foundation for Adolescent

\section{Acknowledgements}

We would like to thank SESI (Social System of Industry) for making available the use of the data for this manuscript, as well as the Núcleo de Pesquisas em Inovação Curricular Research Group, University of Sao Paulo. Also, we want to thank the Knowledge Generation I+D Project; PGC2018-099174-BI00/FEDER Funds for the help provided.

\section{Authors' contributions}

MVD, data collection and data analysis and interpretation. Final review and approval of the version to be published for PTF. Important contributions to the idea and design of the study and final review and approval of the version to be published for MJRC. Everyone have worked on drafting the article and critically reviewed its substantial intellectual content. All authors read and approved the final manuscript.

\section{Funding}

All the sources of funding for the study, collection, analysis, and interpretation of data and in writing of the current manuscript was provided by the Spanish research project PGC2018-099174-B-I00.

\section{Availability of data and materials}

All data generated and analyzed during this study will be treated with total confidentiality. The dataset supporting the conclusions of this article is available by request to the authors.

\section{Competing interests}

The authors declare that they have no competing interests.

Received: 9 August 2019 Accepted: 20 December 2019

Published online: 08 January 2020

\section{References}

Aberastury, A. (2002). La adolescencia normal. Buenos Aires: Paidós ISBN10: 9688532614

Alzina, R. B. (2004). Metodología de la investigación educativa. Madrid: Editorial La Muralla. ISBN: 8471337487

Andrade Neta, N., García-García, E., \& Gargallo, I. (2017). A INTELIGÊNCIA EMOCIONAL NO ÂMBITO ACADÊMICO: Uma aproximação teórica e empírica. 6-52. 51-56. https://doi.org/10.7213/psicolargum.v26i52.19807
Arias, L. I. J., \& Zafra, E. L. (2011). Actitudes sociales y adaptación social en adolescentes españoles: el papel de la inteligencia emocional percibida. Revista de Psicología Social, 26(1), 105-117 https://doi.org/10.1174/ 021347411794078417

Arnal, J., Rincón, D. del, \& Antonio, A. (1992). Investigación educativa: fundamentos y metodologías. Barcelona: Albor. ISBN: 9788433537256

Austin, E. J., Evans, P., Goldwater, R., \& Potter, V. (2005). A preliminary study of emotional intelligence, empathy and exam performance in first year medical students. Personality and Individual Differences, 39(8), 1395-1405 https://doi. org/10.1016/j.paid.2005.04.014

Bar-On, R., \& Parker, J. D. A. (2000). The handbook of emotional intelligence: theory, development, assessment, and application at home, school, and in the workplace. Jossey-Bass. https://doi.org/10.1016/S0160-2896(01)00084-8.

Baron-Cohen, S. (2003). The essential difference: men, women and the extreme male brain. London: Allen Lane. ISBN: 9780713996715

Bigman, Y. E., Mauss, I. B., Gross, J. J., \& Tamir, M. (2016). Yes I can: expected success promotes actual success in emotion regulation. Cognition and Emotion, 30(7), 1380-1387 https://doi.org/10.1080/02699931.2015.1067188.

Blos, P. (1986). Psicoanálisis de la adolescencia. México: Editorial Joaquín Mortiz. ISSN: 0211-5735

Brackett, M. A., Mayer, J. D., \& Warner, R. M. (2004). Emotional intelligence and its relation to everyday behaviour. Personality and Individual Differences, 36(6), 1387-1402 https://doi.org/10.1016/S0191-8869(03)00236-8.

Brackett, M. A., Rivers, S. E., \& Salovey, P. (2011). Emotional Intelligence: Implications for Personal, Social, Academic, and Workplace Success. Social and Personality Psychology Compass, 5(1), 88-103 https://doi.org/10.1111/j. 1751-9004.2010.00334.x.

Brody, L. R. (1993). On understanding gender differences in the expression of emotion: gender roles, socialization, and language. In Human feelings: explorations in affect development and meaning (pp. 87-121). Hillsdale, NJ, US: Analytic Press, ISBN: 0881631442.

Campo, M., Laborde, S., \& Wekemann, S. (2015). Emotional intelligence training: Implications for performance and health. In Advances in Psychology Research. ISBN: 9781634638739

Cohen, J. (1988). Statistical power analysis for the behavioral sciences, (2nd ed., ). Hillsdale, NJ: Lawrence Earlbaum Associates. isbn:978-0-12-179060-8.

Dolev, N., \& Leshem, S. (2017). Developing. Emotional Intelligence Competence among Teachers TeacherDevelopment, 21(1), 21-39 https://doi.org/10.1080/ 13664530.2016.1207093.

Durlak, J. A., Weissberg, R. P., Dymnicki, A. B., Taylor, R. D., \& Schellinger, K. B. (2011). The impact of enhancing students' social and emotional learning: a meta-analysis of school-based universal interventions: social and emotional learning. Child Development, 82(1), 405-432 https://doi.org/10.1111/j.14678624.2010.01564.x.

Extremera, N., Fernández-Berrocal \& Durán, A. (2003). Inteligencia emocional y burnout en profesores. Encuentros en psicología social, 1(5), 260-265. ISSN: 1697-0489

Fernández-Berrocal, P., \& Extremera, N. (2006). Emotional intelligence: A theoretical and empirical review of its first 15 years of history. Psicothema, 18 7-12. ISSN: 02149915

Fernandez-Berrocal, P., Extremera, N., \& Ramos, N. (2004). Validity and reliability of the Spanish modified version of the Trait Meta-Mood Scale. Psychological Reports, 94(3 Pt 1), 751-755 https://doi.org/10.2466/pr0.94.3.751-755.

Fernández-Berrocal, Pablo, \& Pacheco, N. E. (2005). La Inteligencia Emocional y la educación de las emociones desde el Modelo de Mayer y Salovey. 32. ISSN: 0213-8646

Fernández-Berrocal, P., \& Ruiz Aranda, D. (2017). La Inteligencia emocional en la Educación. Electronic Journal of Research in Education Psychology. https://doi. org/10.25115/ejrep.v6i15.12899-370.

Fincias, P. T., Sánchez, E. M., \& Rodriguez-Conde, M. J. (2018). Experimental evaluation of emotional development programmes for teachers in Secondary Education. Anales de psicología, 34(1), 68-76 https://doi.org/10.6018/analesps. 34.1.273451.

Fundaci, I., \& Clouder, C. (2008). Educación Emocional y Social. Análisis Internacional. Reviews of Geophysics., 52-258 https://doi.org/10.1002/ 2013RG000445.Received.

Furr, R. M., \& Funder, D. C. (1998). A multimodal analysis of personal negativity. Journal of Personality and Social Psychology, 74(6), 1580-1591 https://doi.org/ 10.1037/0022-3514.74.6.1580.

Gartzia, L., Aritzeta, A., Balluerka, N., \& Barbera Heredia, E. (2012). Emotional intelligence and gender: beyond sex differences. Anales De Psicología / 
Annals of Psychology, 28(2), 567-575 https://doi.org/10.6018/analesps.28.2. 124111.

Ghanizadeh, A., \& Royaei, N. (2015). Emotional facet of language teaching: emotion regulation and emotional labor strategies as predictors of teacher burnout. International Journal of Pedagogies and Learning, 10(2) https://doi. org/10.1108/JEA-06-2013-0067.

Gilar-Corbi, R., Pozo-Rico, T., Pertegal-Felices, M. L., \& Sanchez, B. (2018). Emotional intelligence training intervention among trainee teachers: a quasiexperimental study. Psicologia: Reflexão e Crítica, 31(1), 33 https://doi.org/10. 1186/s41155-018-0112-1.

Goleman, D. (1996). Inteligencia emocional (4a. ed). Barcelona: Kairós. ISBN: 9788472453715

Guastello, D. D., \& Guastello, S. J. (2003). Androgyny, gender role behavior, and emotional intelligence among college students and their parents. Sex Roles, 49(11-12), 663-673 https://doi.org/10.1023/B:SERS.0000003136.67714.04.

Gur, R. C., Gunning-Dixon, F., Bilker, W. B., \& Gur, R. E. (2002). Sex differences in temporo-limbic and frontal brain volumes of healthy adults. Cerebral Cortex, 12(9), 998-1003 https://doi.org/10.1093/cercor/12.9.998.

Gurgel, I., Pietrocola, M., \& Watanabe, G. (2016). The role of cultural identity as a learning factor in physics: a discussion through the role of science in Brazil. Cultural Studies of Science Education, 11(2), 34 https://doi.org/10.1007/s11422014-9580-5

Gutiérrez-Moret, M., Ibáñez-Martinez, R., Aguilar-Moya, R., \& Vidal-Infer, A. (2016). Assessment of Emotional intelligence in a sample of prospective secondary education teachers. Journal of Education for Teaching: International Research and Pedagogy, 42(2), 123-134 https://doi.org/10.1080/02607476.2016. 1143144.

Huebner, E. S. (1991). Correlates of life satisfaction in children. School Psychology Quarterly, 6(2), 103-111 https://doi.org/10.1037/h0088805.

Jones, S., Eisenberg, N., Fabes, R. A., \& MacKinnon, D. P. (2002). Parents' reactions to elementary school children's negative emotions: relations to social and emotional functioning at school. Merrill-Palmer Quarterly, 48(2), 133-159 https://doi.org/10.1353/mpq.2002.0007.

López de Dicastillo Rupérez, N., Iriarte Redín, C., \& y González Torres, M. (2006). La competencia social y el desarrollo de comportamientos cívicos: la labor orientadora del profesor. Estudios sobre Educación, 1(11), 127-147.

Madalinska-Michalak, J. (2015). Developing Emotional Competence for Teaching. Croatian Journal of Education: Hrvatski Časopis Za Odgoj i Obrazovanje, 17(Sp.Ed.2), 71-97. https://doi.org/10.15516/cje.v17i0.1581

Mayer, J. D. (1997). What is emotional intelligence? En P. Salovey y D. Sluyter (Eds.). Emotional development and emotional intelligence: implications for educators (pp. 3-31). New York: Basic Books. ISBN: 0465095879

Montes-Berges, B., \& Augusto-Landa, J.-M. (2014). Emotional intelligence and affective intensity as life satisfaction and psychological well-being predictors on nursing professionals. Journal of Professional Nursing, 30(1), 80-88 https:// doi.org/10.1016/j.profnurs.2012.12.012.

Parker, J. D. A., Creque, R. E., Barnhart, D. L., Harris, J. I., Majeski, S. A., Wood, L. M., ... Hogan, M. J. (2004). Academic achievement in high school: Does emotional intelligence matter? Personality and Individual Differences. https:// doi.org/10.1016/j.paid.2004.01.002.

Pena Garrido, M., \& Repetto Talavera, E. (2017). Estado de la investigación en España sobre Inteligencia Emocional en el ámbito educativo. Electronic Journal of Research in Educational Psychology, 6(15) https://doi.org/10.25115/ ejrep.v6i15.1284.

Pertegal, M.-Á., Oliva, A., \& Hernando, Á. (2010). Los programas escolares como promotores del desarrollo positivo adolescente. Cultura y Educación, 22(1), 53-66 https://doi.org/10.1174/113564010790935169.

Salavera, C., Usán, P., \& Teruel, P. (2019). The relationship of internalizing problems with emotional intelligence and social skills in secondary education students: gender differences. Psicologia: Reflexão e Crítica, 32(1), 4 https://doi.org/10.1186/s41155-018-0115-a.

Salguero, J. M., Palomera, R., \& Fernández-Berrocal, P. (2012). Perceived emotional intelligence as predictor of psychological adjustment in adolescents: a 1-year prospective study. European Journal of Psychology of Education. https://doi. org/10.1007/s10212-011-0063-8.

Salovey, P., \& Mayer, J. D. (1990). Emotional Intelligence. Imagination, Cognition and Personality, 9(3), 185-211 https://doi.org/10.2190/DUGG-P24E-52WK6CDG.

Salovey, P., Mayer, J. D., Goldman, S. L., Turvey, C., \& Palfai, T. P. (1995). Emotional attention, clarity, and repair: exploring emotional intelligence using the Trait
Meta-Mood Scale. En Emotion, disclosure, \& health (pp. 125-154). https://doi. org/10.1037/10182-006

Saucedo, K. R. R., João, H. A., Chaim, D. F., \& Pietrocola, M. (2018). Rituais de interação e emoções em atividade investigativa com crianças. Educere et Educare. https://doi.org/10.17648/educare.v13i30.18881.

Schutte, N. S., Malouff, J. M., Hall, L. E., Haggerty, D. J., Cooper, J. T., Golden, C. J., \& Dornheim, L. (1998). Development and validation of a measure of emotional intelligence. Personality and Individual Differences, 25(2), 167-177 https://doi. org/10.1016/S0191-8869(98)00001-4.

Toussaint, L., Worthington, E., \& Williams, D. R. (2015). Forgiveness and. Scientific Evidence and Theories Relating Forgiveness to Better Health. Springer: Health https://doi.org/10.1007/978-94-017-9993-5.

Trinidad, D. R. y Johnson, C. A. (2002). The association between emotional intelligence and early adolescent tobacco and alcohol use. Personality and Individual Differences, 32 (1), 95-105. https://doi.org/10.1016/S01918869(01)00008-3

Vergara, A. I., Alonso-Alberca, N., San-Juan, C., Aldás, J., \& Vozmediano, L. (2015). Be water: Direct and indirect relations between perceived emotional intelligence and subjective well-being. Australian Journal of Psychology, 67(1), 47-54 https://doi.org/10.1111/ajpy.12065.

Zeidner, M., Matthews, G., \& Roberts, R. D. (2009). What we know about emotional intelligence: how it affects learning, work, relationships, and our mental health. MIT Press. https://doi.org/10.1080/15332276.2012.11673624.

Zeman, J., \& Garber, J. (1996). Display rules for anger, sadness, and pain: it depends on who is watching. Child Development, 67(3), 957-973 https://doi org/10.2307/1131873

Zeman, J., \& Shipman, K. (1996). Children's expression of negative affect: reasons and methods. Developmental Psychology, 32(5), 842-849. https://doi.org/10. 1037/0012-1649.32.5.842.

Zurita-Ortega, F., Moreno-Arrebola, R., González-Valero, G., Viciana-Garofano, V., MartínezMartínez, A., \& Muros-Molina, J. J. (2018). Revisión conceptual de la conexión entre la inteligencia emocional y la actividad física. SPORT TK: Revista Euroamericana de Ciencias del Deporte, 7(1), 139-144. https://doi.org/ 10.6018/322001.

\section{Publisher's Note}

Springer Nature remains neutral with regard to jurisdictional claims in published maps and institutional affiliations.

\section{Submit your manuscript to a SpringerOpen ${ }^{\circ}$ journal and benefit from:}

- Convenient online submission

- Rigorous peer review

- Open access: articles freely available online

- High visibility within the field

- Retaining the copyright to your article

Submit your next manuscript at $\boldsymbol{\nabla}$ springeropen.com 